\title{
Cultural Video Project Assignment (VPA) through the Eyes of Young ESL Learners: A Multi-Modal Vocabulary Learning Approach
}

\author{
Norina Jabar and Afiza Mohamad Ali* \\ Kulliyyah of Languages and Management, \\ International Islamic University Malaysia \\ (*Corresponding Author) \\ e-mail:drfiza@iium.edu.my
}

\begin{abstract}
:
Learning vocabulary is vital to language proficiency and skills. However, for the ESL learner, vocabulary learning can be challenging due to poor memory and the distinct nature of vocabulary itself. Many studies have looked into vocabulary learning strategies and most have concurred that they should be fun, interactive and meaningful especially for the young ESL learners to recall and use. This paper investigates the effectiveness of video project assignments (VPA) on young learner's vocabulary learning in an ESL reading class. The activity utilizes a combination of project-based learning and multimodal learning platforms like Web 2.0 (Google, YouTube and Padlet). A group of primary five students $(N=30)$ from a public school in Malaysia are examined. The students were exposed to vocabulary items in reading passages on Malaysian culture and asked to discuss them on Padlet. A group video project assignment was also developed and uploaded on Youtube. In this paper, we discuss the quantitative and qualitative findings that show the effectiveness of using multi-modal learning platforms and developing simple, pocket-sized VPAs in enhancing young ESL learners' vocabulary learning.
\end{abstract}

Keywords: vocabulary, video project assignment, Web 2.0, ESL, young learners

Indonesian Journal of EFL and Linguistics, Vol. 1 (2), 2016 


\section{INTRODUCTION}

The importance of vocabulary acquisition to improve one's language proficiency and communication skills has been emphasized by many researchers and practitioners (Alqahtani, 2015; Nunan, 1991; Huckin, 1995). This is supported by Nation (2001) who states that a good command of vocabulary is important to convey a message. For the ESL learner, vocabulary is challenging because the nature of vocabulary is different from the learners' first language. Many studies have looked into vocabulary learning strategies and most have agreed that they should be fun, interactive and meaningful especially for the young ESL learners to recall and use. Especially in this era, educators can use various types of information technologies to teach. Learners will be thrilled and delighted to learn and it is easy to understand. It has been argued that all language professionals need to reflect on the ways in which technology is shifting the perspectives, implications, implementations, etc. of the profession of language teaching (Uzun, 2012). Technology-enhanced virtual learning via Web 2.0 tools for instance can help foster learner-centredness and collaboration (Attwell, 2010). Hence, educators should continue finding ways to take the utmost advantage of such tools for continuous improvement of education.

Many research have justified the positive impact of the internet and web-based technologies in education (Costley, 2014; Wheeler, 2001). A study by Mohd Hafiz Zakaria, Watson and Edwards (2010) research on students in higher education found that Web 2.0 is highly regarded by students. The development of Web 2.0 platforms for example has introduced a new pedagogy for teaching and learning. It also encourages student-centred learning environment and collaborative learning. According to Thompson (2007), Web 2.0 enables people to find information on the internet, create and share content (cited in An, Aworuwa, Ballard and Williams, 2009). Such collaboration enables social interaction to take place as well as deeper sense of comprehension (Chai and Tan, 2010), and higher order thinking because learners generate, plan, and produce their ideas through discussions with instructors, friends, and other people. An example of the use of Web 2.0 platforms is in the creation of video project assignments or VPA in teaching and learning.

The development of video project assignment (VPA) and the use of Web 2.0 platforms relates to the constructivist perspective of education that emphasise a more inventive, realistic, collaborative, and active learning environment for the learners. Constructivism, according to Rajendran N.S. (2010, p.87), is an active, constructive process, where the art of learning is to connect new information to existing knowledge. This is the era where youngsters are born with all sort of modern technologies. So, this enables the students to use modern technologies in the learning process and they will be motivated to learn. He listed several guiding principles of constructivism that are different from traditional ones.

1. Students are trying to construct meaning actively based on the issues around.

2. The learning process focusses on primary concepts and not isolating the facts. 
3. Educators must understand the students' mental models that they use to perceive the world and the assumptions they make to support those models.

4. The students' purpose of learning is to construct their own meaning (or idea) and not just through memorising and "spoon feed" the meaning from someone else.

Research on young ESL learners in Malaysia have found that they are generally unable to acquire English because of the lack of vocabulary. According to Hamidah, Melor and Nor Zaini (2002), other factors to do with students' weaknesses in English include attitude, geographical location and ethnicity (cited in Nor Hashimah Jalaluddin, Norasimah Mat Awal and Kesumawati Abu Bakar, 2008). The language is also foreign to these ESL learners. Furthermore, it is difficult for them to understand the lesson as they need something that can motivate them to learn English. Yamat, Fisher and Rich (2014) reported studies mentioning Malaysian students inability to achieve a reasonable competency level in English despite learning it for 11 years in schools. Researchers have acknowledged that the deteriorating standards of English proficiency will hinder Malaysia's aspiration to be declared a developed nation by 2020 (Nunan, 2003). A study by Mohd Sofi Ali (2003), found that language performance among primary school children has not improved tremendously despite having learnt the language for six years as students are exposed to reading comprehension and writing with very limited time allocated for listening and speaking. It has been suggested that real vocabulary learning happens only if the vocabulary is used both receptively and productively by the learners (Nation, 2001).

Hence, the paper aims to increase the young learners' vocabulary in English and to find out the impact of using video project assignment or VPA on young learners. This paper puts forth the research questions below:

1. Is there any statistically significant difference in vocabulary learning performance between ESL young learners' pre- and post-test measures via Web 2.0 platforms?

2. What are the perceptions of ESL young leaners in developing VPA and using Web 2.0 platforms?

\section{LITERATURE REVIEW}

\subsection{Young Learners and ESL Vocabulary Learning}

In vocabulary learning among children, reading is thought to be one of the most important ways to acquire L2 vocabulary incidentally. Studies have shown how incidental learning occurs by mean of the number of exposures to unknown items during the reading process, in which the learner guesses meaning from context or consult a dictionary (Hulstijn, 2005). While the role of reading in second language vocabulary learning is usually recognized, studies suggest that incidental learning only results in meaning recognition but not in production (Pitts et al., 1989; Horst et al., 1998). Alternatively, there is more vocabulary yield and retention when students 
are exposed to reading-based exercises ie exposure to explicit target items via word exercises (Hill and Laufer, 2003; Min, 2008; Laufer and Rozovski-Roitblat, 2011; Ma and Sin, 2015).

Ma and Sin (2015) investigated a group of 25 primary three pupils in a Hong Kong primary school on how their receptive learning and productive learning affect L2 young learners' vocabulary retention over a period of 5 weeks over 5 lessons for 35 minutes each. The pupils were taught English vocabulary as part of their reading lesson under two conditions: (i) reading with only receptive learning exercises or (ii) reading with both receptive and productive learning exercises. The results showed that the condition involving both receptive and productive exercises led to more vocabulary retention than the condition with receptive exercises only. This is justified as incremental knowledge of a word happens with multiple exposures in meaningful contexts (Stahl, 2010).

Similar receptive and productive technique can be seen in Seal (1991) who classified vocabulary teaching strategies as planned and unplanned activities in classrooms (cited in Chin, 2004). He further explains that the unplanned strategies refer to occasions when words may be learned incidentally and accidentally in class when students request particular meanings of the word, or when the teacher becomes aware of any relevant words to which attention needs to be drawn. He proposed a three C's method; conveying, checks, and consolidated. The first method is conveying meanings to confirm that students understand what has been conveyed. The second method is where a teacher needs to check the meanings to confirm that students understand what has been conveyed. The last method is called consolidated which is by practicing the vocabulary in contexts as the word needs to fit into the world (Stahl, 2005). Hence, placing the vocabulary in context in reading activities or tasks while ensuring receptive and productive learning would be more meaningful. Nonetheless, Berne and Blachowicz (2008), found that teaching vocabulary may be problematic because many teachers are not confident about the best practice in vocabulary teaching. It is in the context of this study that this vocabulary learning activity be made more pertinent when assisted by a multi-modal learning approach.

\subsection{Multi-modal Vocabulary Learning Approach}

The internet is seen as a robust learning tool for ESL learners to discover and learn new vocabulary effectively. There are many platforms that they can use, for exampl; Google, Mozilla, Explorer and so forth. Not only that, web applications can attract students' attention in language learning, for example the use of Padlet, Youtube, Kahoot and many more (Richardson, 2009). According to Tozcu and Coady (2004), words can be taught more effectively and in an enjoyable and even amusing way with the use of computers and Web-based materials.

According to Daloglu, Baturay and Yildirim (2009, p.187), Web-based vocabulary learning adopts a constructivist approach which emphasises the following features; 
i. Learner-centeredness: Learners have freedom to study or work at their own specified time. They can freely choose their study time, the number of visits to the Web site and frequency of working exercises.

ii. Contextualised meaning and knowledge construction: The lesson is simpler and attractive because vocabulary was represented through various contexts and enriched with the use of multimedia tools (pictures and sound).

iii. Opportunities for production: Learners engaged in activities that required meaningful interaction, critical thinking, and genuine language production.

iv. Immediate feedback: Learners received immediate feedback about their language productions and improved their learning.

v. Ongoing / periodic recycling: Participants are able to use this Web-based tool for the revision of vocabulary items that had been learned and studied in class, and the tool provided multiple and spaced encounters with the language to be learned.

According to Benson and Chick (2010), the globalised online spaces such as YouTube, Flicker, and Facebook, enable students to constructively share and discuss an array of digital artefacts in their work autonomously, creatively and collaboratively (An, Aworuwa, Ballard and Williams, 2009). The digital nativity of students nowadays would ensure that they will be motivated and excited to do tasks that are related to the use of Web 2.0. A good way to benefit from this is via studentcentered project-based learning approach (Warschauer, Schetzer, \& Meloni, 2000).

\subsection{Project-based Learning Approach}

Research have shown that multimodal digital compositions activities like video project assignment make way for learners to construct their own independent ideas as part of the learning process (Haffner and Miller, 2011). This corresponds to constructivism theory of learning as students in the classroom, interact with real data, primary resources, the teacher and with each other which entail the formation of new knowledge (Brooks and Brooks, 1999). The use of Web 2.0 enables students to upload their videos on YouTube which supports active and social learning, provide opportunities for student publication, effective feedback as well as opportunities to scaffold learning towards student's development (Hartshorne and Ajjan, 2009).

The approach of creating Video Project Assignment or VPAs by students can encourage them to take control of the tasks, communicate and work together to achieve the learning outcome collaboratively. According to Miller (2009), such communicative pedagogical approaches encourage students to participate in their learning more fully. The constructivist approach shifts the responsibility for learning onto learners, which helps to motivate them in their learning process (Hafner and Miller, 2011). Hafner and Miller (2011) reported a research they conducted which was part of a course development effort on English for Science and Technology for university students in Hong Kong. Students were asked to carry out a digital video 
project using a "pedagogy for multiliteracies" like Web 2.0 (ibid, p.68) with a focus on learner autonomy. The study found that the use of digital story-telling projects has high potential to promote learner interest and engagement as, “... students work either individually or in groups to design and construct a short, movie-like digital production, known as a digital story." Strong learner autonomy was reported as students were responsible for monitoring and reflecting on their own learning. Learner motivation increased as the task was deemed as enjoyable and innovative. Most importantly, the project can serve as an alternative means of expression for the weaker learners (Bull and Kajder, 2004).

Nonetheless, caution was exercised in the extent of freedom given to the students in creating a video project particularly on the importance of a structured assignment with clear outcomes (Hafner and Miller, 2011). They cited Kajder and Swenson (2004) and Ohler (2006), who stressed the need to understand digital story projects as means to encourage students to focus on the story and language usage as opposed to the technology.

\section{RESEARCH METHODOLOGY}

This study was carried out in an ethnographic manner in which the researchers were also the facilitators and the project advisors. Commencement of the video project was based on the needs of the lesson, such as the need to make learning the language a more enjoyable and relevant for the students. The aim of the English lesson was to enhance their English vocabulary learning via video project assignment development. The research is conducted using quasi-experimental research design. The participants' grouping for this research was approved by the headmistress in the school being researched according to the students' level of English proficiency.

\subsection{Participants}

The sample of the study were thirty $(\mathrm{N}=30)$ ESL primary 5 school students from a local public school in a state in Malaysia. The participants were divided into two groups; control and experimental group.

\subsection{Data Collection and Analysis}

The data included observations of the students' work progress, conversations and discussions with them at various stages of the project implementation, the artefacts made by the students, and the students' focus group interview.

\subsection{The Video Project Assignment}

The present study adapted Hafner and Miller's "architecture of the technological learning environment" research design, which employed (a) planning, (b) filming and editing, and (c) sharing processes. However, the third part was modified to suit students' English level (see Figure 1.0). The structured project was developed over a period of 7 weeks within a 1 hour lesson per week. The students were informed regarding the outcome of the 7-week lesson which was to produce a video project on Malaysian culture. Students were guided on the assignment but given the freedom to 
explore and find the knowledge and vocabulary independently. They then had to bring their findings to class and place them on Padlet.

Figure 1: Architecture of the technological learning environment. (adapted from Hafner and Miller, 2011)

\begin{tabular}{|c|c|c|c|}
\hline Stage of project & Planning & Filming \& Editing & Sharing \\
\hline $\begin{array}{l}\text { Technology } \\
\text { Utilised }\end{array}$ & $\begin{array}{ll}\text { - } & \text { Online Dictionary } \\
\text { - } & \text { Google Search } \\
\text { - } & \text { Googine } \\
\text { - } & \text { Padlet Translation } \\
\text { - } & \text { Google Images } \\
\text { - } & \text { Wikipedia } \\
\end{array}$ & $\begin{array}{ll}\text { - } & \text { Padlet } \\
\text { - } & \text { Movie Media Maker } \\
& 6.0 \\
\text { - } & \text { Google Translation } \\
\text { - } & \text { Google Search } \\
& \text { Engine } \\
\text { - } & \text { Online Dictionary } \\
\end{array}$ & $\begin{array}{l}\text { - } \text { Padlet } \\
\text { - } \text { Youtube } \\
\text { - } \text { Movie Media Maker } \\
6.0 \\
\text { - } \text { VLE Frog }\end{array}$ \\
\hline In-class Support & $\begin{array}{l}\text { Reading Workshop } \\
\text { Grammar Workshop }\end{array}$ & $\begin{array}{l}\text { Video Workshop } \\
\text { Youtube - Online } \\
\text { Streaming }\end{array}$ & \\
\hline Course Schedule & \multicolumn{3}{|l|}{ Week 1} \\
\hline
\end{tabular}

\subsubsection{Planning}

As part of the planning stage of the project, students were initially asked to work in groups of six. Each group was given a Padlet site address to

$\rightarrow$ assemble pictures they captured or retrieved from the internet,

$\rightarrow$ write descriptions about the picture (and not losing the notes), and

$\rightarrow$ get information from the link posted by the teacher to them.

The students were taught on how to use the Google Search Engine and Wikipedia in order to obtain as much background knowledge and information on the topic. All information and pictures were saved in each group's Padlet account. The students were also instructed to use online dictionaries or Google translate if they faced difficulties in understanding the words. They also had to explain about the pictures taken from Google Images Search Engine in their own words. This method was used to ensure the students generated the words through experience. They used Padlet to document all of their findings because, the school does not allow the students to bring any electronic devices like cell phones and laptops. Nonetheless, they were allowed to upload pictures taken on their cellphone at home to be uploaded on their Padlet. 
Figure 2.0: Sample of students' work on Padlet

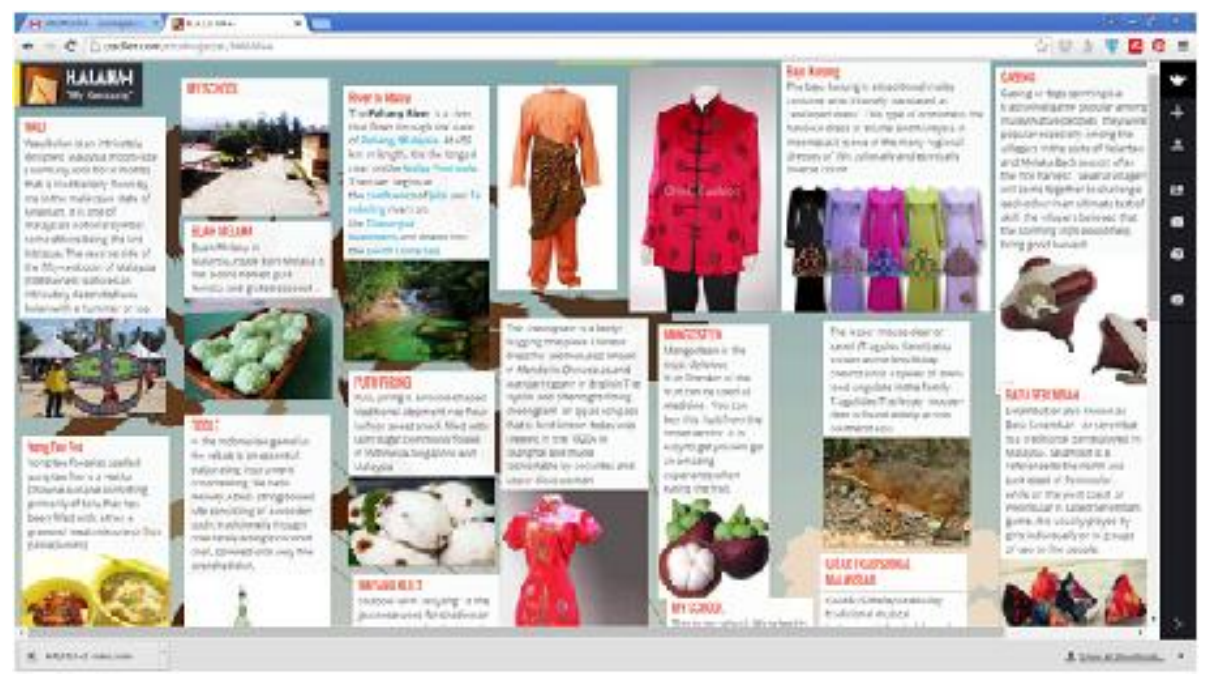

\subsubsection{Filming and Editing}

Next, the students were taught on how to use the Windows Movie Maker 6.0 (WMM 6.0) via Youtube tutorials and were given time to practise using the software application by uploading and arranging all the saved pictures and videos on Padlet to WMM 6.0.

Figure 3.0 Students work on Windows Movie Maker

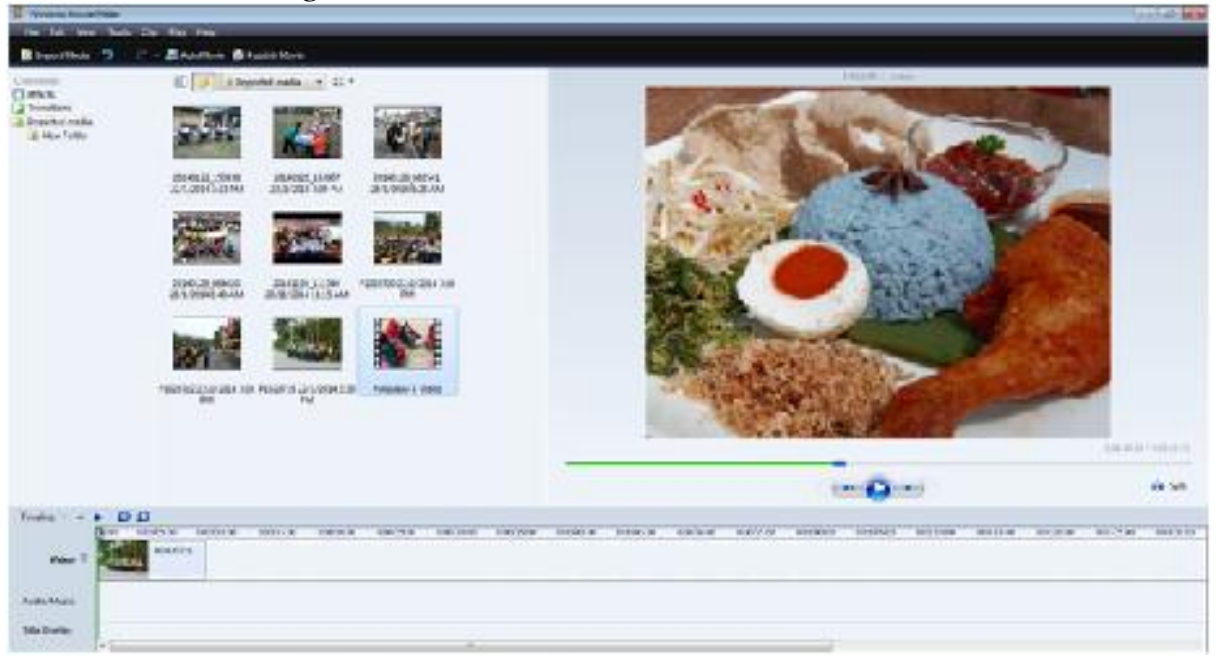

They were also instructed to describe their project by labelling and describing the pictures using simple sentences. The students took the opportunity to rephrase the sentences or create their own sentences using Google Translation or online dictionary. They were guided to correct their sentences as they could not rely $100 \%$ on Google Translation. Next, they linked songs to their project's by uploading them to WMM 6.0. They then needed to write a script telling about their project. All recordings were done by the students at home. Students' projects were assessed for 
overall satisfactory work once they have completed the draft version of their video project on Padlet,

\subsubsection{Sharing}

A new Youtube account was created to upload the video projects online. Students were instructed to watch other group members' video projects and respond by giving comments.

\section{FINDINGS}

Research Question 1: Is there any statistically significant difference in vocabulary learning performance between ESL young learners' pre- and post-test measures via Web 2.0 platforms?

Table 1: Results of paired sample t-test

Paired Samples Statistics

\begin{tabular}{|cc|c|c|c|c|}
\hline & Mean & N & $\begin{array}{c}\text { Std. } \\
\text { Deviation }\end{array}$ & $\begin{array}{c}\text { Std. Error } \\
\text { Mean }\end{array}$ \\
\hline Pair 1 & PRE TEST & 23.00 & 30 & 9.879 & 1.804 \\
& POST TEST & 69.00 & 30 & 14.227 & 2.598 \\
\hline
\end{tabular}

Paired Sample Test

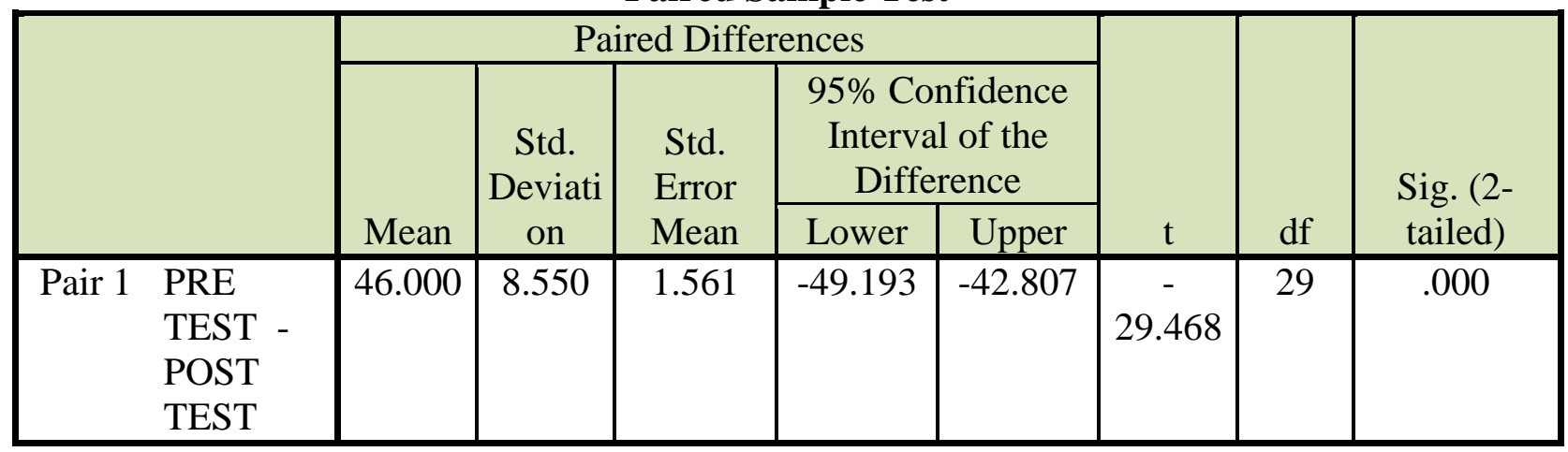

A paired-samples t-test was conducted to compare the effectiveness of VPA in enhancing students' vocabulary in pre-test and post-test. There was a significant difference in the scores for pre-test $(\mathrm{M}=23.00, \mathrm{SD}=9.88)$ and post-test $(\mathrm{M}=69.00$, $\mathrm{SD}=14.227)$ conditions; $\mathrm{t}(29)=29.47, \mathrm{p} \leq 0.05$. These results suggest that the use of VPA does have a positive effect in enhancing young ESL learners' vocabulary. Specifically, the results suggest for the use of VPA for ESL young learners as part of their learning process. 
Research Question 2: What are the perceptions of the students in developing VPA and using Web 2.0 platforms?

Two groups were selected for the focus group interview - the Elite Group (Group A) and Haiana+I (Group B), Each group comprised of 6 primary school students. Two interview sessions were conducted in their native language (Bahasa Melayu) in order to gage their responses as much as possible on the interview questions. The interview session was conducted for the purpose of seeking feedback from the participants after 7 weeks of learning vocabulary through the use of Web 2.0.

The first question asked was "Do you enjoy learning English?". Students from both groups mentioned that they enjoyed the English lessons tremendously particularly when working on the video project as it was exciting and fun, "I really like to make the video project as it was so much fun and exciting". When asked further on "What was the most interesting part of the experience?", a student from Group B said that she enjoyed uploading and arranging pictures in Windows Movie Maker 6.0. Another student from the same group said that she found writing words and describing pictures on the movie itself as interesting. The third student from Group B said that, "I like to search for music to be uploaded on the media I worked on." One of the students from Group A said, "I like it when the video is done because I love to hear my voice recording reading the script." Furthermore, the Group B students were laughing when they heard their own as well as their friends' recordings.

A girl from Group B shared her experience using the VIVA Video with the teacher. It can be noticed that the use of VIVA Video was easier because the students captured videos using the application. It took only 15 minutes for the students to edit and come up with a video. Unfortunately, the students were not allowed to bring any electronic device to school. So, the Windows Movie Maker 6.0 was used instead and installed on each computer available in the school with the help of the school computer technician. In conclusion, the students enjoyed the lesson in completing a task given. One student from Group B said that she enjoyed working on Padlet especially when their work was displayed on screen using a projector. Most of the scripts written on the screen were produced by her.

When asked the next question, "What have you learned from this course?", one student from Group B said, "I improved my vocabulary and use of online dictionary really quick which helped me a lot in preparing the script". Another student added, "I used my phone to look for the meaning of words when writing my English essay." when what he really meant was that he preferred to use the online dictionary instead of the conventional one. According to him, it took some time to find words using the conventional dictionary because the dictionary contains base words. For example, the word "originating", can only be found in the dictionary as "originate". This may slow down his learning process in looking for the meaning of words. Interestingly, one of his friends from Group A suggested to install the "English Malay, Malay English" dictionary on his phone. In addition, when asked whether they used any other medium for script preparation, the students mentioned the use of "Google Translate" and this was because it was much easier to translate the words directly 
into their native language (Bahasa Melayu), rather than using the conventional way of looking for unfamiliar words.

For the following questions - "What was the most interesting part of the class? And why?", and "What was the most enjoyable aspect of the video project? Why?, most of the responses given were focused on the visual and audio aspects of the application used for their project, ie. "I like to work with Windows Movie Maker 6.0 because I can describe my presentation based on the pictures and upload my favourite songs in it." This indicates how the applications helped in motivating the students' towards writing in English as a result of having acquired the vocabulary through reading, exposure and practice in using the same words repeatedly with the quick access to the online dictionaries and search engines. Some of the students agreed that they enjoyed working on Padlet and search engines, because these platforms allowed them to find attractive pictures via 'Google Images'. Their Padlets enabled them to write or type description of images on their Padlet assigned to them. They were more encouraged especially when their project was showcased for all to see using the LCD projector in class. This seemed to mean that the students developed their confidence in letting their friends witness their work together in class. In doing so, the students felt proud, encouraged and motivated to complete their projects collaboratively and creatively in a highly enjoyable and stimulating environment.

\section{Figure 4: Students' VPA on Youtube}

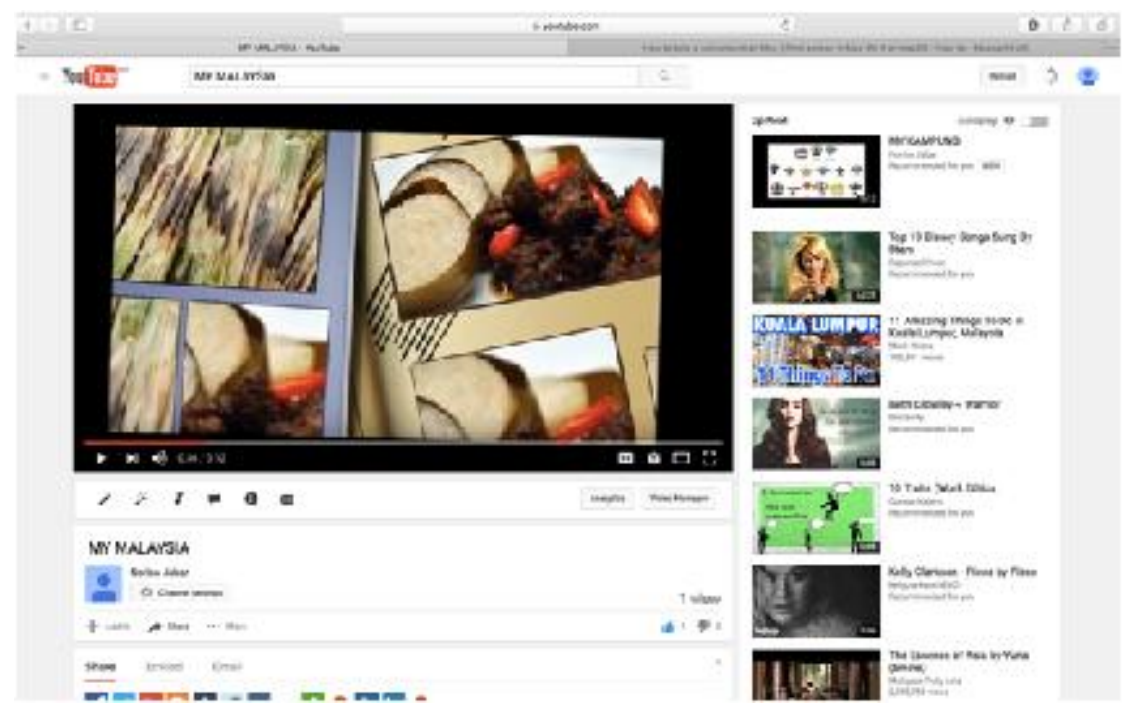

In one of the projects entitled 'My Malaysia', one student stated that,

"I like to make the video because we can tell the world about things in Malaysia through uploading our video on YouTube and it is really enjoyable. It is great to see number of viewers liking our video with via the 'thumbs up' icon to mean 'Like'." 
One student added that the number of likes can be a motivating factor as "the more the merrier and popular". The use of the search engines by these young learners proved to be an enriching experience for them as well, as one student put it, "With Google Search Engine, I can get unlimited access of information there and I learn so many new words about travel Malaysia." The exposure to the software applications in class can be also be seen as a valuable training experience for the students to develop Web 2.0 skills ie. publishing their work online seemed to make them think that it is 'live on television' for the public to see, which was a proud moment for one student,

"I enjoyed putting the effects and transition using the Media Movie Maker 6.0. and then see how they look and appear on Youtube. I was excited. Is that really our work on TV??? I feel so proud!"

The exposure was not just realized as a benefit to the students themselves but to the world outside. When asked the final question, "What was the most useful thing that you learned by doing the video project? And why?", most of the students mentioned that the VPA could serve and help people 'out there' to learn more about Malaysia in a very short time. In addition, the students agreed that the assignment helped them to be more well-read by reading a lot of information via the search engines. This helped them gather new vocabulary apart from the ones they were exposed to. They also agreed that they liked learning English via the assignment as it was associated with the real world, especially when it was technology-assisted like using the computer and internet.

Nonetheless, there were also shortcomings faced by the students during the project completion. When asked "What problems did you encounter when doing the video project?, one of the students said that she expected teamwork and cooperation in completing the task given to them. This was also due to the fact that the students met for only an hour a day every week to complete their video project during English class. The students found it difficult to gather their friends outside of school hours because some of them lived very far. Another limitation was the fact that students found it challenging to gather photos, videos, and information because the school did not allow them to bring electronic devices to school. One of the solutions given earlier to them was to assemble all pictures and scripts on their Padlet site which made it possible for them to save their effort and work on their project anytime and anywhere as Padlet could be accessed through phones and tablets.

Saving their work was also an issue as some of them did not own sophisticated devices like the thumb drive or bluetooth. The students solved the issues themselves as some of them owned mobile phones and most had internet access (Wi-Fi) hence managed to get all the pictures of traditional delicacies, traditional games, local fruits etc. They also managed to purchase prepaid internet for RM10 to enable them to download video maker applications on to their phones. This enabled them to make their own videos using their handphones before sharing the videos with their group members via WhatsApp. What can be seen here is that the students were highly resourceful and dedicated in making sure that they accomplished the task 
given. Most importantly, the activity made learning English enjoyable, innovative and authentic.

\section{DISCUSSION}

It can be seen from the quantitative findings that the exposure to Web 2.0 via VPA enhanced the students English vocabulary skills. This corresponds to the research on the benefits of Web 2.0 as a teaching and learning tool (An, Aworuwa, Ballard and Williams, 2009). In general, students' perception toward using the tools was also positive. The students were motivated to learn English, as they enjoyed looking for information via the search engines and searched for word meanings using the online dictionaries as they drove them to look further to understand the words in different context especially when they had the chance to explore the knowledge by themselves. This corresponds to studies on the positive effect of the use of edictionaries on learners' incidental vocabulary learning (Laufer and Hill (2001). Most importantly, they retained the words learnt longer because they experienced, searched, and practiced using the words repetitively. The integration of multimodality platforms via the video project assignment proved to be highly supportive tools in helping students to enrich their vocabularies. Not only that, the students understood the need to negotiate, discuss and plan their work collaboratively to ensure the completion of their project. This agrees with Dam (1995) on the notion that students become "sensitized to the socialization process of working collaboratively and adopt different ways of thinking about their language learning" (cited in Hafner and Miller, 2011, p. 70).

The students were very excited when there were other viewers who watched their video projects as they saw a greater purpose in completing their projects and that could serve others' needs as well. From a social contructionist viewpoint, this finding aligns itself with Dam's (1995, p.1, cited in Hafner \& Miller, 2011) definition of learner autonomy which "is characterized by a readiness to take charge of one's own learning in the service of one's needs and purposes. This entails a capacity and willingness to act independently and in cooperation with others, as a socially responsible person". Furthermore, the students shared their projects using the VLE Frog (or Virtual Learning Environment) in which their videos were uploaded there to be viewed by students and parents all over Malaysia. The VLE Frog is an e-learning platform used widely in schools in Malaysia and is accessible to every student. Each student is given an ID and password to upload and download resources, access to homework given by their teachers, search for information and many more. The benefit of using this is that it allows the teachers, parents and students to access the account. Using the same ID and password that their children have, the parents can easily access and get updated on their children's learning progress and potential. This paper reports findings that indicate that the students' possessed 'literacy of web' whereby they are reasonably at ease in using the various types of web application tools, including a range of Web 2.0 applications and media. This is supported by the research by Mohd Hafiz Zakaria, Watson \& Edwards (2010) who found that student' learning preferences and expectations are more inclined to inclusive and exclusive use of IT tools in the classroom. 
Few suggestions can be derived from the study. Firstly, the results have shown that students seem to feel more at ease and relaxed to use search engines to get information compared to approaching their teacher. Second, students were enthusiastic to learn about the search engines, and other applications like dictionaries and movie maker which drove them to explore the tools further with their friends. Students' responses have indicated that hands-on activity like the video project assignment enabled them to explore and construct knowledge together, findings which are similar to Hafner and Miller's (2011). This is pertinent to infuse a fun and inventive learning atmosphere in the English classroom, especially for these generation of students. Third, the qualitative findings indicate the students love for technology at such a young age.

Hence, the education establishment assumes an important role in encouraging the use of technology especially Web 2.0 in the classrooms as seen in the findings. Although students in this study were not allowed to bring handphones to school, the facility provided by the language lab ie access to the internet and Youtube was fundamental. This study puts forth few considerations for the educator, namely, the needs and expectations of the Web 2.0 generation of students, the robustness of the activities provided for learning ie. video project assignment using the tools and the readiness of the learning institution in allowing originality and innovation in teaching and learning of vocabulary for young learners. The guided VPA in this study also provided some cushion to the notion of students' publication of content to public domain. This goes back to the benefits of receptive and productive notions of vocabulary learning research by Ma and Sin (2015) and Seal (1999). Nonetheless, teachers should be prepared themselves in introducing such approach as it may require extra preparations with regards to the many online tools and strategies, for sustaining students' engagement.

\section{CONCLUSION}

In conclusion, although this study is restricted to thirty 11 year-olds, the data obtained provides some insights into how young learners are able to use the internet and software applications easily via structured and guided video project assignments for vocabulary learning. The productive skills translated via their video project 'vocabulary-learning' assignment reinforced the words they learned earlier prior to the activity which were henceforth used as key words when they used they search engines. In general, the positive findings show how the young learners were easily adapted, open and eager to learn and experiment with the new technologies. They did not appear passive in the context of content construction contrary to findings by Mohd Hafiz Zakaria, Watson \& Edwards (2010) on university students. In general, these Malaysian young learners were receptive and positive towards the use of Web 2.0 for vocabulary learning. This also signals the need for a dedicated and wholesome teaching strategy to optimise the impact of such multi-modal approach in teaching vocabulary in schools as teachers and students, both hold a mutual obligation to merit a kind of learning that yields the intended outcome, away from old-fashioned classroom limitations. 


\section{REFERENCES}

Alqahtani, M (2015). The Importance of Vocabulary in Language Learning and How to be Taught. International Journal of Teaching and Education. Vol. iii, No. 3. From http://www.iises.net/international-journal-of-teachingeducation/publication-detail-213

An, Y.J., Aworuwa, B., Ballard, G., and Williams, K. (2009). Teaching with Web 2.0 Technologies: Benefits, Barriers and Best Practices. College of Liberal Arts and Education, Texas A\&M University-Texarkana.

Attwell, G and Hughes, J. (2010). Pedagogic Approach to Using Technology for Learning. (Pntydysgu) for Lifelong Learning. Skills for Learning Professional. UK.

Benson, P. \& Chick, A. (2010). New literacies and autonomy in foreign language learning. In M.J. Luzon, M.N. Ruiz-Madrid, \& M.L. Villanueva (Eds), Digital genres, new literacies and autonomy in language learning. Newcastle: Cambridge Scholars. $63-80$.

Berne, J.I., \& Blachowicz, C.L.Z. (2008). What Reading Teachers Say About Vocabulary Instruction: Voices from the Classroom. The Reading Teacher, 62(4), 314-323.

Brooks, J.G. and Brooks, M.G. (1999). In Search of Understanding: The Case for Constructivist Classrooms. With a New Introduction by the Authors. Association for Supervision and Curriculum Development Alexandria, Virginia USA. Pp. 103 from

http://ocw.metu.edu.tr/pluginfile.php/9173/mod_resource/content/1/In\%20Searc $\mathrm{h} \% 20 \mathrm{of} \% 20$ Understanding.pdf

Bull, G. and Kajder, S. (2004) Digital Story Telling in the Language Arts Classroom. Learning and Leading with Technology, 32(4), 46 - 49. From http://www.primaryaccess.org/guide/DigitalStorytelling.pdf

Chin, C. (2004) EFL Learners' Vocabulary Development in the Real World: Interests and Preferences. English Teaching, 59(2), 43 - 58 from http://journal.kate.or.kr/wp-content/uploads/2015/02/kate_59_2_3.pdf

Coady, J., and Huckin, T. (Eds). (1997). Second Language Vocabulary Acquisition. Cambridge: Cambridge University Press.

Costley, K.C. (2014). The Effects of Technology on Teaching and Student Learning. Arkansas Tech University. 2 - 3.

Dam, L. (1995). Learner autonomy 3: From theory to classroom practice. Dublin: Authentik.

Davies, T., and Williamson, R. (1998). The Ghost in the Machine: Are "teacherless" CALL programs really possible? Canadian Modern Language Review, 55(1), 8 $-18$.

Daloglu, A., Baturay, M., and Yildirim. (2009). Chapter XII Designing a Constructivist Vocabulary Learning Materials. IGI Global. p. 187, and 192.

Enonbun, O (2010). Constructivism and Web 2.0 in the Emerging Learning Era: A Global Perspective. Central Michigan University. Journal of Strategv Innovation and Sustainability Vol. 6(4). Pp. 18.

Glaserfeld E. (2000) Problems of Constructivism. 
from http://www.univie.ac.at/constructivism/EvG/papers/233.pdf

Hafner, C.A. \& Miller, L. (2011). Fostering Learner Autonomy in English for Science: A Collaborative Digital Video Project in a Technological Learning Environment. Language Learning \& Technology. Volume 15, Number 3. 6886. From http://llt.msu.edu/issues/october2011/hafnermiller.pdf

Hamidah Yamat, Melor Md. Yunus \& Norzaini Azman. (2002). English Language Proficiency for Quality in Education: Are Our Students Ready? Proceedings of International Conference on Education for All. 225 - 233.

Hartshorne, R., and Ajjan, H. (2009). Examining Student Decisions to Adopt Web 2.0 Technologies: Theory and Empirical Tests. Journal of Computing in Higher Education, 21(2). from http://doi.org/10.1007/s12528-009-9023-6

Hill, M. and Laufer, B. (2003). Type of task, time-on-task and electronic dictionaries in incidental vocabulary acquisition, International Review of Applied Linguistic, 41, 2: 87-106.

Jalaluddin, N. H., Awal, N. M., \& Bakar, K. A. (2008). The mastery of English language among lower secondary school students in Malaysia: A linguistic analysis. European Journal of Social Sciences, 7(2), 106-119.

Kajder, S., and Swenson, J.A. (2004). Digital Images in the Language Arts Classroom. Learning and Leading with Technology, 31(8), 18 - 46.

Labrie, G. (2000). A French vocabulary tutor for the Web. Calico Journal, 17(3), $475-500$.

Laufer, B., \& Hill, M. (2000). What lexical information do L2 learners select in a CALL dictionary and how does it affect word retention? Language Learning \& Technology, 3(2), 58-76. From http://lit.msu.edu/vol3num2/lauferhill/index.html

Laufer, B. and Rozovski-Roitblat, B. (2011). Incidental vocabulary acquisition: The effects of task type, word occurrence and their combination, Language Teaching Research, 15, 4: 391-411.

Ma, Qing and Sin, Ching Ha. (2015). Teaching Young Learners English Vocabulary with Reading-Based Exercises in a Real Classroom Situation. Porta Linguarum 23, enero 2015. From

http://www.ugr.es/ portalin/articulos/PL_numero23/8\%20\%20MA\%20Qing.pd $\mathrm{f}$

Miller, L. (2009). Reflective lesson planning: Promoting learner autonomy in the classroom. In R. Pemberton, S. Toogood, \& A. Barfield (Eds), Maintaining control: Autonomy and language learning (pp. 109 - 124). Hong Kong: Hong Kong University Press.

Min, H. T. (2008). EFL vocabulary acquisition and retention: reading plus vocabulary enhancement activities and narrow Reading, in Language Learning, 58, 1: 73-115.

Mohd Hafiz Zakaria, Jason Watson, Sylvia L. Edwards, (2010) Investigating the use of Web 2.0 technology by Malaysian students, Multicultural Education \& Technology Journal, Vol. 4 Iss: 1, pp.17 - 29 
Mohd. Sofi Ali (2003). English Language Teaching in Primary Schools: Policy and Implementation Concerns. International Languages Teacher Training Institute Lembah Pantai, Kuala Lumpur. IPBA E-Journal, from https://kajianberasaskansekolah.files.wordpress.com/2008/04/article70.pdf

National Institute of Child's Health and Human Development. (2000). Report of the National Reading Panel: Teaching children to read. An evidence based assessment of the scientific research literature on reading and its implications for reading instruction (NH Publications No. 00 - 4769). Washington D.C.: U.S. Government Printing Office.

Nation, I.S.P. (2001). Learning Vocabulary in Another Language. Cambridge: Cambridge University Press. From

http://catdir.loc.gov/catdir/samples/cam031/2001269892.pdf

Nunan, D. (1991). Language Teaching Methodology: A textbook for teachers. London: Prentice Hall.

Nunan, D. (2003). The Impact of English as a Global Language on Educational Policies and Practices in the Asia-Pacific Region. TESOL Quarterly, 37(4), 589 - 613. From http://dx.doi.org/10.2307/3588214

Ohler, J. (2006). The World of Digital Storytelling. Educational Leadership, 63(4), $44-47$.

Rajendran N.S. (2010). Teaching and Acquiring Higher-Order Thinking Skills Theory and Practices. Universiti Pendidikan Sultan Idris Tanjong Malim, Perak, pp. $9-10$.

Richardson, W. (2009). Blogs, Wikis, Podcasts and Other Powerful Web Tools for Classrooms $\left(2^{\text {nd }}\right.$ ed). Thousand Oaks, CA: Corwin Press.

Seal, B.D. (1991) Vocabulary Learning and Teaching. In M. Celce-Murcia (Ed.), Teaching English as a Second or Foreign Language (pp. 296 - 311). Boston, MA: Heinle \& Heinle Publishers.

Thompson, J. (2007). Is education 1.0 ready for web 2.0 students? Innovate, 3(4).

Tozcu, A., \& Coady, J. (2004). Successful learning of frequent vocabulary through CALL also benefits reading comprehension and speed. Computer Assisted Language Learning, 17(5), 473 - 495.

Uzun, Levent. (2012). The Internet and computer-mediated artefacts for foreign language learning and practice, and intercultural communication: MOODLE, Second Life, and others. Procedia - Social and Behavioral Sciences 46. 3296 3300 .

Warschauer, M., Schetzer, H., \& Meloni, C. (2000). Internet for English Teaching. Alexandria, VA: TESOL.

Wheeler, S. (2001). Information and Communication Technologies and the Changing Role of the Teacher. Journal of Educational Media, Vol. 26, No(1), $\mathrm{Pp} ; 7-17$

Yamat, H., Fisher, R., \& Rich, S. (Vol. 10, No.3; 2014). Asian Social Science: Revisiting English Language Learning among Malaysian Children. Canadian Center of Science and Education. 